\title{
The Determinant of Capital Structure of SMEs in Malaysia: Evidence from Enterprise 50 (E50) SMEs
}

\author{
Asmawi Noor Saarani ${ }^{1} \&$ Faridah Shahadan ${ }^{2}$ \\ ${ }^{1}$ Institute of Malaysian and International Studies, Universiti Kebangsaan Malaysia, Malaysia \\ ${ }^{2}$ Faculty of Economic and Management, Universiti Kebangsaan Malaysia, Malaysia \\ Correspondence: Asmawi Noor Saarani, Institute of Malaysian and International Studies, Universiti Kebangsaan \\ Malaysia, 43600 Bangi, Malaysia. E-mail: sasmawi@gmail.com
}

Received: March 14, 2013 Accepted: March 30, 2013 Online Published: April 28, 2013

doi:10.5539/ass.v9n6p64 URL: http://dx.doi.org/10.5539/ass.v9n6p64

\begin{abstract}
Capital structure have implications in determining the ability and success of a firm, especially to small and medium-sized enterprises (SMEs). This paper analyses the capital structure of SMEs in Malaysia focusing on Enterprise 50 (E50) SMEs. E50 is an annual awards program initiated by government and organized by SME Corporation \& Deloitte Malaysia since 1997 to recognize the 50 best SME companies in Malaysia based on their performances and potential to succeed. The secondary data from Companies Commission of Malaysia has been collected for the study. The study employed regression analysis on 334 companies, utilised the accounting data for the five year period of 2005 to 2009. Capital structure is the Dependent Variable referring to debt ratio of the companies, decomposed into Long Term Debt ratio and Short term Debt ratio. The Independent Variables (IV) are age; size; tangibility; liquidity; profitability; growth and taxation. Two theories of capital structure have guided this study i.e. the Trade-Off Theory and the Pecking Order Theory. The study found that size is important if we decomposed the debt into longand short term. In addition, asset tangibility, liquidity and profitability are the main capital structure determinants for SMEs. Age and growth are important for a long term, while taxation is not an important consideration in capital structure decision.
\end{abstract}

Keywords: capital structure, determinant factors, regression analysis

\section{Introduction}

The context of this paper is the financial management of to small and medium-sized enterprises (SMEs) particularly on the determination of SMEs capital structure. According to Brealey and Myers (1988), the capital structure will determine the survival of a business. In economics, capital is one of the factors of production as well as land, labor and entrepreneurs (Ali, 2005; Vengedasalam \& Madhavan, 2007). In this study, it refers to the financing needed by SMEs to operate and expand the business. The sources of the financing consist of equity provided by the owner and shareholders and in the form of debt by borrowing from banks and financial institutions. In corporate finance, the composition of capital financing in the form of equity and debt is known as capital structure (Ross, Westerfield, \& Jordan, 2011; Watson \& Wilson, 2002).

Capital structure is the subject of behavioral studies that examine the financing of a company. In managing the capital structure, a company must have a clear separation of its debt to equity ratio. The financial records of all of the company's transactions must be monitored and maintained in an efficient account management system. Overall, the capital structure is the basis for understanding the impact of the investments and expenses of a particular company's business.

Most of the previous studies in capital structure focused on large listed companies for both developed and developing countries (Rajan \& Zingales, 1995). This could be due to the higher accessibility of the data for large and listed companies. Nevertheless, the scientific community has started to pay attention to the small companies as an object of the study (López-Gracia \& Sogorb-Mira, 2008). A realization of the significant economic contribution of SMEs has resulted in increased attention focused on the sector from policy-makers and academics. According to Ang (1991), it is important to have an empirical study for SMEs, as it is believe that the modern corporate finance theory was developed without small business in minds.

Therefore, the objective of this paper is to analyze the capital structure of small and medium-sized enterprises 
(SMEs) in Malaysia focusing on Enterprise 50 (E50). E50 is an annual awards program initiated by government and organized by SME Corporation \& Deloitte Malaysia since 1997 to recognize the 50 best SME companies in Malaysia based on their performances and potential to succeed. A key feature of the empirical studies reported in this paper is the utilization of the secondary data of SMEs.

The paper is divided into five sections. Section 1 is the introduction. Section 2 focuses on the related literature consist of major capital structure theories that can be used to explain the financing decisions in the business. Section 3 explain the methodology, identifies the main attributes suggested by previous studies, leading to the definition of the hypotheses and the model to be tested. Section 4 discusses the results obtained and section 5 concludes the study.

\section{Theory on Capital Structure}

Well known as MM theorem, the Modigliani and Miller (1958) stated that in the efficient market where there is no taxes, bankruptcy costs, agency costs, and asymmetric information, the value of a company is unaffected by the way the company is financed. However, in reality, the assumptions are irrelevance. Therefore in 1963, Modigliani and Miller considered the implication of taxes on debt versus equity in the companies' capital structure and Miller (1977) addressed the issue more specifically, showing that under some conditions, the optimal capital structure can be complete debt finance due to the preferential tax treatment of debt relative to equity.

Following the discourse, two leading theories emerged and widely referred to in the study of capital structure. The theories are: 1) Trade-off Theory (see e.g. Kraus \& Litzenberger, 1973); and 2) Pecking Order Theory (Donaldson, 1961; Myers, 1984; Myers \& Majluf, 1984).

The Trade-off Theory of capital structure refers to the equilibrium between debt and equity financing after taking into account the cost of financial distress due to bankruptcy and tax benefit of borrowing (Kraus \& Litzenberger, 1973). Profits can reduce costs and improve financial distress by increasing the tax benefits of debt. Companies are more likely to choose debt financing up to a certain level where the cost of financial distress start to surface. Type of assets owned by the companies will determine the cost. For example, if a company has a considerable portion of the land or property and tangible assets, they would have less financial distress compared to companies that rely on intangible assets. Normally, for debt financing the company needs to provide a guarantee in the form of collateral. In this case, the SMEs are always seen as having a higher risk because typically SMEs have less tangible assets and low profit (Pettit \& Singer, 1985). In this regard it is expected that tangibility has positive relationship to the leverage and taxes have a negative relationship.

On the other hand, the Pecking Order Theory (Myers \& Majluf, 1984) is based on the idea of asymmetric information between managers and investors. According to Myers (1984), companies prioritize their sources of financing and prefer internal financing. If the external financing is needed, the debt will be chosen and equity will be the last resort. Managers know more about the value of the companies than investors. To avoid the underinvestment problem, managers will seek to finance the new project using a security that is not undervalued by the market, such as internal funds or riskless debt. Therefore, this affects the choice between internal and external financing. The pecking order theory is able to explain why companies tend to depend on internal sources of funds and prefer debt to equity if external financing is required. Thus, a companies' leverage is not driven by the trade-off theory, but it is simply the cumulative results of the companies' attempts to mitigate information asymmetry. Hence, profitability is expected to have negative relation with leverage. Previous studies on listed companies such as Titman \& Wessels (1988), and Rajan \& Zingales (1995) found negative relationship. Studies on SMEs also confirm the pecking order relationship (Sogorb-Mira, 2003). Therefore, it is expected profitability to be inversely related to leverage.

\section{Methodology}

The methodology will describe the model specification, data source, the proposed hypothesis, identify the variables and the measurement as well as the econometric model.

\subsection{Model Specification}

The following model was employed for the analysis:

$$
\begin{aligned}
\text { Capital } & =\beta_{0}+\beta_{1}(\text { Age })_{i}+\beta_{2}(\text { Size })_{i}+\beta_{3}(\text { Tangibility })_{i}+\beta_{4}(\text { Liquidity })_{i}+ \\
\text { Structure } & \beta_{5}(\text { Profitability })_{i}+\beta_{6}(\text { Growth })_{i}+\beta_{7}(\text { Taxation })_{i} \\
\text { (Leverage })= & +\mathrm{U}_{i}
\end{aligned}
$$


The Ordinary Least Square (OLS) regression is run on SPSS version 19. The model is derived on the basis of previous studies such as Ozkan (2001) and Ramlall (2009).

\subsection{Data}

From 1998 until 2009, a total of 600 SMEs have received the E50 award. Some companies have won more than once. Therefore, after taking into account this factor, there are 405 SMEs have won during that period. Data of these 405 SMEs was gleaned from Companies Commission of Malaysia. However only 349 SMEs available with a complete data set for the five year period of 2005 to 2009. Furthermore, due to the presence of outliers, some companies had to be removed. Finally only 334 companies are used for further analysis.

\subsection{Variable and Hypothesis}

This paper examines the capital structure as a Dependent Variable (DV). The DV is the leverage or Total Debt Ratio (TDR) measured by Total Debts/Total Assets. Sogorb-Mira (2003) argued that to get better understanding on leverage, Long Term Debt Ratio (LDR) measured by Long Term Debt/ Total Assets and Short Term Debt Ratio (SDR) measured by Short Term Debt/Total Assets should be evaluated separately.

Independent Variable (IV) or explanatory variable that has been identified include age, size, tangibility, liquidity, profitability, growth, investment and taxation.

\subsubsection{Age}

Age of the business is fundamental in the study of capital structure of the companies (Bhaird, 2010). For this reasons, the financial provider such as banks evaluate the creditworthiness and reputation of the SMEs over sometime. According to Berger and Udell (1998), the variety of financing needs is related to the business life cycle requirement which again is related to the age of the business. Sources of financing depend on whether a business is developing or maturing. Start-up companies normally source their financing need through personal saving, friends and relatives (Faridah \& Madeline, 2004). As companies grow and mature, different types of debt requirement become important until a company is ready to enter the capital market and obtain external financing (Berger \& Udell, 1998; Wijst \& Thurik, 1993). Thus, the following hypothesis is proposed to test the age factor:

$H 1$ : There is a positive relationship between the age of SMEs and the leverage ratio.

The age variable is measured by the number of years SME was in the business by looking at the date of the registration until the year of 2011 (see Esperança, Gama, \& Gulamhussen, 2003; Abor, 2007; Ramlall, 2009).

\subsubsection{Size}

Romano, Tanewski, and Smyrnios (2001) found that company's size is among the significant variables associated with leverage. Comparatively, some previous studies define size in a number of ways including number of employees (Berggren, Olofsson, \& Silver, 2000), natural logarithm of total asset (Sogorb-Mira, 2003), and sales (Abor, 2007) as a proxy to the variables. Regardless of the proxy used, most of the studies find that the long-term debt has a positive relationship with leverage. On contrary, short term debt has a negative relationship. Therefore, to verify the finding, the following hypotheses are proposed:

H2 : There is a positive relationship between the size of SMEs and the leverage ratio.

$H 2 a$ : There is a positive relationship between the size of SMEs and the Long Term Debt.

$H 2 b \quad$ : There is a negative relationship between the size of SMEs and the Short Term Debt.

Operationally, the size variable is measured by natural logarithm of total assets (Sogorb-Mira, 2003; Ramlall, 2009).

\subsubsection{Tangibility}

Tangible assets have a positive relationship with leverage due to the value added provided by the collateral (Esperança, Gama, \& Gulamhussen, 2003). This finding is in line with earlier prominent research such as Titman and Wessels (1988) and Rajan and Zingales (1995) who found a positive relationship between an aggregate measure of tangible assets, including land, buildings and equipments, with leverage. Business whose assets are suitable as security for loans tend to use debt rather heavily. General purpose assets that can be used by many businesses make good collateral, where as special purpose assets do not. Thus, real estate companies are usually highly leveraged, while companies in technological research are not (Brigham \& Houston, 2007). In term of duration, Chittenden, Hall, and Hutchinson (1996) find a positive relationship between tangibility and long-term debt, but a negative relationship between tangibility and short-term debt. The following hypothesis will be tested to verify the argument: 
$H 3$ : There is a positive relationship between the asset tangibility and leverage.

$H 3 a$ : There is a positive relationship between the asset tangibility and Long Term Debt

$H 3 b$ : There is a negative relationship between the asset tangibility and short term debt.

This variable is measured as the ratio of net fixed assets over total assets (Abor, 2007; Esperança, Gama, \& Gulamhussen, 2003; Ramlall, 2009).

\subsubsection{Liquidity}

Liquidity addresses the sufficiency of a stock of high quality liquid assets to meet short-term liquidity needs under a specified acute stress scenario. Brealey and Myers (1988) argued that the relationship is negative. On contrary, Sibilkov (2009) claimed that leverage is positively related to asset liquidity. According to Kila and Mansor (2009), the relationship between liquidity and capital structure need to be considered in the view that liquidity has a significant impact on debt ratios. A negative relationship exists due to the potential liquidity of the conflict between shareholders and lenders, however, liquidity can also produce positive effects in the high liquidity can facilitate lending (Ozkan, 2001). In this regard the proposed hypothesis:

H4 : There is a negative relationship between the liquidity and leverage.

The liquidity variable is measured by Current Assets divided by Current Liabilities (Damodaran, 2001).

\subsubsection{Profitability}

Based on the Pecking Order Theory, profitability will indicate the level of cash adequacy and less reliance on debt. Therefore, this theory predicts a negative relationship between profitability and financial leverage (Myers, 1984). This view is in tandem with the claims of (Jensen, 1986) that under inefficient market, the lenders are reluctant to offer debt even though the company is making profit, because the lenders have no control over the company. However if the market is efficient, the relationship will be positive (Jensen, 1986). In order to verify this argument, the proposed hypothesis is:

H5 : There is a negative relationship between the profitability and leverage.

The variable is measured by the ratio of Net Profit on Total Assets (Abor, 2007; Ramlall, 2009).

\subsubsection{Growth}

Growth refers to the investment opportunity or project that has the potential to grow significantly, bringing profit to the companies (Ross et al., 2011). New project are often presented to investor and shareholder, as growth opportunities. Since this opportunity can represent a significant fraction of the company value, it would be foolish to forgo them in order to pay out all the earning as dividends to investors and shareholders.

According to (Fama \& French, 2002), companies with more growth opportunities will need less debt. In tandem with Myers (1977), highly leveraged companies with growth opportunities face an underinvestment problem which leads them to forgo investment projects with a positive net present value. Therefore, by reducing debt, companies avoid the agency problem in which the benefits obtained by bondholders are from shareholders if the investment or project is carried out. However, Michaelas, Chittenden, and Poutziouris (1999) claimed that there is a positive relationship between growth and short term debt. In line with the arguments, the propose hypothesis is:

\footnotetext{
H6 : There is a negative relationship between the growth opportunity and leverage.

H6a : There is a negative relationship between the growth opportunity and Long Term Debt.

$H 6 b$ : There is a positive relationship between the growth opportunity and Short Term Debt.
}

The growth variable is measured by dividing intangible assets over total assets (Titman \& Wessels, 1988; Michaelas, Chittenden, \& Poutziouris, 1999).

\subsubsection{Taxation}

According to Modigliani and Miller (1963), company would prefer debt financing due to the tax deductibility of interest payment. Despite the broad consensus among the previous researcher regarding the positive impact of tax on leverage the empirical evidence remain inconclusive. In fact Myers (1984) claimed that there were no 
studies that clearly showed on how company tax status affects the company debt policy. So the hypothesis to be tested is:

$H 7$ : There is a positive relationship between tax and leverage.

Proxy for measurement of this variable is Tax divided by the Profit before Tax (Sogorb-Mira, 2003).

\section{Result and Discussion}

\subsection{Descriptive Statistics of Capital Structure and the Determinant Factors}

A summary of the descriptive statistics of the variables is presented in Table 1. On average, total debt amounted to $53 \%$ of total assets value. If we decomposed it into long term (i.e. more than one year) and short term (i.e. less than one year), estimated long term debt is $11 \%$ and short term is $42 \%$. Average age of the SMEs who have won E50 awards is 20 years. Size mensured by mean of asset value is shown as RM74.5 million. On the average, $35 \%$ of E50 SMEs total assets were in the form of fixed assets. In term of liquidity, E50 SMEs have the sufficiency of $195 \%$ to meet is short term obligation. As far as profitability is concern, the average return on assets over the period of study mounts up to $25 \%$. With respect to growth, intangible assets represent over $3 \%$ of total assets value. The average tax rate of E50 is $17.9 \%$, which is lower than the standard corporate tax rate in Malaysia of $25 \%$.

Table 1. Descriptive statistics of dependent and independent (explanatory) variables

\begin{tabular}{|c|c|c|c|c|c|c|}
\hline \multicolumn{2}{|c|}{ Variable } & $\mathrm{N}$ & Mean & SD & Minimum & Maximum \\
\hline \multirow{3}{*}{$\begin{array}{l}\text { Dependent } \\
\text { Variable }\end{array}$} & Total Debt & 334 & 0.5305 & 0.2084 & 0.0663 & 0.9879 \\
\hline & Long Term Debt & 334 & 0.1103 & 0.1119 & 0.0000 & 0.5832 \\
\hline & Short Term & 334 & 0.4201 & 0.2066 & 0.0340 & 0.9879 \\
\hline Independent & Age & 334 & 19.96 & 7.67 & 3 & 44 \\
\hline \multirow[t]{6}{*}{ Variable } & Size & 334 & 7.4510 & 0.5854 & 5.4100 & 9.4700 \\
\hline & Tangibility & 334 & 0.3562 & 0.2001 & 0.0000 & 0.9058 \\
\hline & Liquidity & 334 & 1.9547 & 1.6339 & 0.2654 & 12.3741 \\
\hline & Profitability & 334 & 0.2583 & 0.2246 & 0.0000 & 0.9197 \\
\hline & Growth & 334 & 0.0338 & 0.0757 & 0.0000 & 0.6246 \\
\hline & Taxation & 334 & 0.1798 & 0.1318 & 0.0000 & 0.6433 \\
\hline
\end{tabular}

\subsection{Correlation}

To evaluate the possible degree of collinearity among variable, the correlation matrix of dependent and independent variables has been examined and presented in Table 2. As shown in table 2, the correlation coefficient shows that multicollinearity is not an issue of concern for regression. Therefore this model is valid for regression analysis.

Table 2. Correlation matrix

\begin{tabular}{|c|c|c|c|c|c|c|c|c|c|c|}
\hline & TDR & LDR & SDR & AGE & SIZE & TANG & $\begin{array}{l}\text { LQ } \\
\end{array}$ & PROF & GRO & TAX \\
\hline TDR & 1.000 & & & & & & & & & \\
\hline LDR & .284 & 1.000 & & & & & & & & \\
\hline SDR & .855 & -255 & 1.000 & & & & & & & \\
\hline AGE & -192 & -.020 & -182 & 1.000 & & & & & & \\
\hline SIZE & -.075 & .160 & -162 & .421 & 1.000 & & & & & \\
\hline TANG & -.050 & .450 & -294 & .076 & .103 & 1.000 & & & & \\
\hline LIQ & -644 & -.062 & -615 & .114 & -.023 & -237 & 1.000 & & & \\
\hline PROF & -.550 & -167 & -464 & .043 & .046 & -.083 & .427 & 1.000 & & \\
\hline GRO & -.155 & -.033 & -139 & -.006 & -.069 & .200 & .033 & .049 & 1.000 & \\
\hline TAX & .047 & -.074 & .087 & .034 & -.027 & -.099 & -100 & .028 & -169 & 1.000 \\
\hline
\end{tabular}




\subsection{Regression}

The key determinant factors infleucing capital structrue of SMEs can be seen from the summary of regression result presented in Table 3. For comparison with the propose hypotheses, the direction of relationship and significance between the capital structure determinants and the debt ratio is presented in table 4. Total Debt Ratio (TDR) reflects the overall picture of the Capital Structure of E50 SMEs. From this perspective, only liquidity, profitability and growth match with the proposed hypotheses. Size and taxation also did not correspond with the proposed hypothesis, however the relationship is not significant. On the other hand, the Long Term Debt Ratio (LDR) and Short Term Debt Ratio (SDR) result is in tandem with the proposed hypothesis on size. With respect to tangibility, even though the TDR result are contrast with the proposed hypothesis, the LDR and SDR result match perfectly.

Table 3. Regression Result

\begin{tabular}{|c|c|c|c|}
\hline \multirow{2}{*}{$\begin{array}{l}\text { Independent } \\
\text { Variable }\end{array}$} & \multicolumn{3}{|c|}{ Dependent Variables } \\
\hline & TDR & LDR & SDR \\
\hline \multirow[t]{2}{*}{ Constant } & 0.905 & -0.177 & 1.083 \\
\hline & $(9.102)^{* * *}$ & $(-2.469)^{*}$ & $(12.444)^{* * *}$ \\
\hline \multirow[t]{2}{*}{ AGE } & -0.002 & -0.002 & 0.000 \\
\hline & $(-2.176)^{*}$ & $(-2.681)^{* *}$ & $(-0.275)$ \\
\hline \multirow[t]{2}{*}{ SIZE } & -0.001 & 0.032 & -0.033 \\
\hline & $(-0.052)$ & $(3.187)^{* *}$ & $(-2.690)^{* *}$ \\
\hline \multirow[t]{2}{*}{ TANGI } & -0.217 & 0.275 & -0.492 \\
\hline & $(-5.497)^{* * *}$ & $(9.668)^{* * *}$ & $(-14.263)^{* * *}$ \\
\hline \multirow[t]{2}{*}{ LIQUIDITY } & -0.070 & 0.011 & -0.081 \\
\hline & $(-13.442)^{* * *}$ & $(2.891)^{* *}$ & $(-17.754)^{* * *}$ \\
\hline \multirow[t]{2}{*}{ PROFITABILITY } & -0.298 & -0.095 & -0.203 \\
\hline & $(-8.198)^{* * *}$ & $(-3.610)^{* * *}$ & $(-6.393) * * *$ \\
\hline \multirow[t]{2}{*}{ GROWTH } & -0.202 & -0.179 & -0.023 \\
\hline & $(-2.001)^{*}$ & $(-2.454)^{*}$ & $(-0.263)$ \\
\hline \multirow[t]{2}{*}{ TAXATION } & -0.055 & -0.011 & -0.044 \\
\hline & $(-0.966)$ & $(-0.275)$ & $(-0.878)$ \\
\hline R-Squared & 0.600 & 0.278 & 0.689 \\
\hline F-(p-value) & $60.903(0.0000)$ & $15.606(0.0000)$ & $89.851(0.0000)$ \\
\hline No of observation & 334 & 334 & 334 \\
\hline
\end{tabular}


Table 4. Correlation between the determinants and the debt ratio

\begin{tabular}{|c|c|c|c|c|c|c|}
\hline \multirow{3}{*}{$\begin{array}{l}\text { Independent } \\
\text { Variables (The } \\
\text { determinants) }\end{array}$} & \multicolumn{6}{|c|}{ Dependent Variables (Debt Ratio) } \\
\hline & \multicolumn{2}{|c|}{ TDR } & \multicolumn{2}{|c|}{ LDR } & \multicolumn{2}{|c|}{ SDR } \\
\hline & HYPHOTESIS & RESULT & HYPHOTESIS & RESULT & HYPHOTESIS & RESULT \\
\hline AGE & $\mathrm{H} 1:+\mathrm{ve}$ & $\begin{array}{l}\text {-ve, } \\
\text { significant }\end{array}$ & - & $\begin{array}{l}\text {-ve, } \\
\text { significant }\end{array}$ & - & $\begin{array}{l}+\mathrm{ve} \\
\text { not significant }\end{array}$ \\
\hline SIZE & $\mathrm{H} 2:+\mathrm{ve}$ & $\begin{array}{l}-\mathrm{ve}, \\
\text { not significant }\end{array}$ & H2a:+ve & $\begin{array}{l}+\mathrm{ve}, \\
\text { significant }\end{array}$ & $\mathrm{H} 2 \mathrm{~b}:-\mathrm{ve}$ & $\begin{array}{l}\text {-ve } \\
\text { significant }\end{array}$ \\
\hline TANGI & H3:+ve & $\begin{array}{l}\text {-ve, } \\
\text { significant }\end{array}$ & H3a:+ve & $\begin{array}{l}+v e, \\
\text { significant }\end{array}$ & H3b:-ve & $\begin{array}{l}\text {-ve } \\
\text { significant }\end{array}$ \\
\hline LIQUIDITY & H4:-ve & $\begin{array}{l}-\mathrm{ve}, \\
\text { significant }\end{array}$ & - & $\begin{array}{l}\text { +ve, } \\
\text { significant }\end{array}$ & - & $\begin{array}{l}\text {-ve } \\
\text { significant }\end{array}$ \\
\hline PROFITABILITY & H5:-ve & $\begin{array}{l}\text {-ve, } \\
\text { significant }\end{array}$ & - & $\begin{array}{l}\text {-ve, } \\
\text { significant }\end{array}$ & - & $\begin{array}{l}\text {-ve } \\
\text { significant }\end{array}$ \\
\hline GROWTH & H6:-ve & $\begin{array}{l}-\mathrm{ve}, \\
\text { significant }\end{array}$ & H6a:-ve & $\begin{array}{l}\text {-ve, } \\
\text { significant }\end{array}$ & H6b:+ve & $\begin{array}{l}-\mathrm{ve} \\
\text { not significant }\end{array}$ \\
\hline TAXATION & H8:+ve & $\begin{array}{l}\text {-ve, } \\
\text { not significant }\end{array}$ & - & $\begin{array}{l}\text {-ve, } \\
\text { not significant }\end{array}$ & - & $\begin{array}{l}\text {-ve } \\
\text { not significant }\end{array}$ \\
\hline
\end{tabular}

The analyses of each variable are as follows:

\subsubsection{Age}

The age variable showed a negative relationship instead of positive sign expected. In addition, the relationship is statistically significant. This finding is similar to Esperança et al. (2003). This result can be interpreted within the context of Pecking Order Theory. Older and more experience companies require less external financing as they can rely more on internally generated fund.

\subsubsection{Size}

The size variable showed a negative sign. This result contradict with the proposed hypothesis, however the relationship is not significant. If we decompose the analysis into LDR and SDR the results match perfectly. The results suggest that the bigger the company, the more external financing it will use. One possible reason is that, the big companies are more diversified and therefore have steady earning, enable them to manage high debt ratio. Small companies may seek short-term financing more often due to their lower diversification and generally perceived as high risk.

\subsubsection{Tangibility}

Contrary to the proposed hypotheses of the tangibility variable, the result showed a negative relationship. So we reject the H3. Nevertheless, the relationship changes significantly according to long term and short term category. Precisely, the LDR is positively correlated with tangibility, while this correlation becomes negative if we compared to SDR. The result is similar to Wijst and Thurik (1993), Chittenden et al. (1996), and Sogorb-Mira (2003).

\subsubsection{Liquidity}

In line with the proposed hypotheses of the variable liquidity, the result showed a significant negative relationship. Therefore the $\mathrm{H} 4$ is accepted. Liquidity reflects the ability of the companies to deals with their short term liabilities. High liquidity companies use less debt and indicate that there finance their business operation following Pecking Order Theory.

\subsubsection{Profitability}

The significant negative relation showed between profitability and total debt ratio confirms the proposed hypothesis H5. The result indicates that less profitable companies are more likely to need external financing. The 
result is consistent with Pecking Order Theory and previous studies and (Titman \& Wessels, 1988) and (Abor, 2007).

\subsubsection{Growth}

From the growth perspective, the result shows a negative and statistically significant relationship with the total debt ratio and LDR. Therefore, H6 and H6a are accepted. On the other hand, SDR show contradicting result with the H6b, however the correlation is insignificant. Growing companies place a higher demand on the internally generated funds. Thus, companies with a relatively high growth rate will tend to focus on accumulated retain earnings then short term debt before long term debt to finance their growth. This finding supports the Pecking Order Theory that claims that companies have a preference order for capital used to finance the investments.

\subsubsection{Taxation}

The results indicate a negative and statistically insignificant relationship between tax and total debt ratio. The result is contradict with Trade Off theory that suggest that a company chooses how much debt finance and how much equity finance by balancing the costs of financing and the tax benefits. Previous research with the similar finding (Pettit \& Singer, 1985) claimed that SMEs are less likely to be profitable and therefore will not benefit from the tax advantage.

Results show that what determines the optimal capital structure is still an ongoing and complex matter. Indeed, this study has shown a mixture finding. For example, this study finds significant negative relationship between leverage and age and the relationship is positively insignificant if we decomposed it into short term ratio.

Size and tangibility are both positively correlated with long term debt. In term of tangibility, negative correlation with short term may evidence that SMEs try to match their fixed assets with long term debt and their current assets with short term debt. Liquidity generates its negative effect on leverage indicating that companies with high liquidity have the ability to generate high cash inflows for their business activities. Hence, lesser debt will be utilized. On contrary, low liquidity firms, tend to go for debt financing. Profitability and growth are important determinants in explaining the E50 capital structure. However, taxation does not explain the leverage needs.

\section{Conclusion}

This study focuses on the determinants of capital structure of SMEs in Malaysia which have won the Enterprise 50 awards. These companies have been chosen for the study due to the fact that these companies have been perceived as a benchmark for successful SMEs and have potential for further advancement. In order to get a more thorough understanding of the underlying factors that drive the financing decision particularly in SME sector, this paper have tested some empirical hypotheses over a panel data of 334 E50 SMEs during 2005-2009.

Most of the results in this study consistent with main theories in finance to explain capital structure within the companies i.e. The Pecking Order Theory and Trade Off Theory. Following from the finding of this study, future direction of research might consider investigating further the contradicting insignificant finding in size and taxation.

\section{Acknowledgements}

The authors would like to thank the Public Services Department of Malaysia for sponsoring this research.

\section{References}

Abor, J. (2007). Debt policy and performance of SMEs: Evidence from Ghanaian and South African firms. Journal of Risk Finance, 8(4), 364-379. http://dx.doi.org/10.1108/15265940710777315

Ali, H. (2005). Comprehensive Economics Guide. Singapore: Oxford University Press.

Ang, J. S. (1991). Small Business Uniqueness and the Theory of Financial Management. Journal of Small Business Finance, 1(1), 1-13.

Berger, A. N., \& Udell, G. F. (1998). The economics of small business finance: The roles of private equity and debt markets in the financial growth cycle. Journal of Banking \& Finance, 22, 613-673. http://dx.doi.org/10.1016/S0378-4266(98)00038-7

Berggren, B., Olofsson, C., \& Silver, L. (2000). Control Aversion and The Search for External Financing in Swedish SMEs. Small Business Economics, 15(3), 233-242. http://dx.doi.org/10.1023/A:1008153428618

Bhaird, C. M. A. (2010). The Modigliani-Miller Proposition After Fifty Years and Its Relation to Entrepreneurial Finance. Strategic Change: Briefings in Entrepreneurial Finance, 19.

Brealey, R. A., \& Myers, S. C. (1988). Principles of Corporate Finance (3rd ed.). Singapore: McGraw-Hill 
International Editions.

Brigham, E. F., \& Houston, J. F. (2007). Fundamentals of Financial Management (11th ed.). Ohio: Thomson South-Western.

Chittenden, F., Hall, G., \& Hutchinson, P. (1996). Small Firm Growth, Access to Capital Markets and Financial Structure: Review of Issues and an Empirical Investigation. Small Business Economics, 8(-), 56-67.

Damodaran, A. (2001). Corporate Finance: Theory and Practice (2 ed.). New York: Wiley.

Esperança, J. P., Gama, A. P. M., \& Gulamhussen, M. A. (2003). Corporate debt policy of small firms: an empirical (re)examination. Journal of Small Business and Enterprise Development, 10(1), 62-80. http://dx.doi.org/10.1108/14626000310461213

Fama, E. F., \& French, K. R. (2002). Testing Trade-Off and Pecking Order Predictions About Dividends and Debt. The Review of Financial Studies, 15(1), 1-33. http://dx.doi.org/10.1093/rfs/15.1.1

Faridah, S., \& Madeline, B. (2004). Pembiayaan Industri Skala Kecil di Malaysia. In R. Ismail (Ed.), Industri Kecil Malaysia: Isu Pembiayaan, Teknologi dan Pemasaran (pp. 37-66). Kuala Lumpur: Pusat Pengajian Ekonomi, Universiti Kebangsaan Malaysia.

Jensen, M. C. (1986). Agency Costs of Free Cash Flow, Corporate Finance and Takeovers. American Economic Review, 76, 323-329.

Kila, S. M., \& Mansor, W. M. W. (2009). Capital Structure and Firm Characteristics: Some Evidence from Malaysian Companies. Munich Personal RePEc Archive (MPRA).

Kraus, A., \& Litzenberger, R. H. (1973). A State Preference Model of Optimal Financial Leverage. Journal of Finance, 28(4), 911-922. http://dx.doi.org/10.1111/j.1540-6261.1973.tb01415.x

López-Gracia, J., \& Sogorb-Mira, F. (2008). Testing Trade-Off and Pecking Order Theories Financing SMEs. Small Business Economics, 31(2), 117-136. http://dx.doi.org/10.1007/s11187-007-9088-4

Michaelas, N., Chittenden, F., \& Poutziouris, P. (1999). Financial Policy and Capital Structure Choice in U.K. SMEs: Empirical Evidence from Company Panel Data. Small Business Economics, 12(2), 113-130. http://dx.doi.org/10.1023/A:1008010724051

Miller, M. H. (1977). Debt and Taxes. The Journal of Finance, 32(2), 261-275.

Modigliani, F., \& Miller, M. H. (1958). The Cost of Capital, Corporate Finance and the Theory of Investment. The American Economic Review, 48(3), 261-296.

Modigliani, F., \& Miller, M. H. (1963). Corporate income taxes and the cost of capital: A correction. American Economic Review, 53, 433-443.

Myers, S. C. (1977). Determinants of corporate borrowing. Journal of Financial Economics, 5, 147-175. http://dx.doi.org/10.1016/0304-405X(77)90015-0

Myers, S. C. (1984). The Capital Structure Puzzle. The Journal of Finance, 39(3), 575-592. http://dx.doi.org/10.2307/2327916

Myers, S. C., \& Majluf, N. S. (1984). Corporate financing and investment decisions when firms have information that investors do not have. Journal of Financial Economics 13, 187-221. http://dx.doi.org/10.1016/0304-405X(84)90023-0

Ozkan, A. (2001). Determinants of Capital Structure and Adjustment to Long Run Target: Evidence from UK Company Panel Data. Journal of Business and Accounting, 28(1), 175-198. http://dx.doi.org/10.1111/1468-5957.00370

Pettit, R. R., \& Singer, R. F. (1985). Small Business Finance: A Research Agenda. Financial Management, 14(3), 47-60. http://dx.doi.org/10.2307/3665059

Rajan, R. G., \& Zingales, L. (1995). What Do We Know about Capital Structure? Some Evidence from International Data. The Journal of Finance, 50(5), 1421-1460. http://dx.doi.org/10.1111/j.1540-6261.1995.tb05184.x

Ramlall, I. (2009). Determinants of Capital Structure Among Non-Quoted Mauritian Firms Under Specificity of Leverage: Looking for a Modified Pecking Order Theory. International Research Journal of Finance and Economics, (31), 84-92.

Romano, C. A., Tanewski, G. A., \& Smyrnios, K. X. (2001). Capital structure decision making: A model for 
family business. Journal of Business Venturing, 16(3), 285-310. http://dx.doi.org/10.1016/S0883-9026(99)00053-1

Ross, S. A., Westerfield, R. W., \& Jordan, B. D. (2011). Essentials of Corporate Finance (7th ed.). New York: McGraw-Hill Irwin.

Sibilkov, V. (2009). Asset Liquidity and Capital Structure. Journal of Financial and Quantitative Analysis, 44(5), 1173-1196. http://dx.doi.org/10.1017/S0022109009990354

Sogorb-Mira, F. (2003). How SME Uniqueness Affects Capital Structure: Evidence From a 1994-1998 Spanish Data Panel. SSRN eLibrary. http://dx.doi.org/10.2139/ssrn.393162

Titman, S., \& Wessels, R. (1988). The Determinants of Capital Structure Choice. The Journal of Finance, 43(1), 1-19. http://dx.doi.org/10.1111/j.1540-6261.1988.tb02585.x

Vengedasalam, D., \& Madhavan, K. (2007). Principles of Economics. Shah Alam: Oxford Fajar.

Watson, R., \& Wilson, N. (2002). Small and Medium Size Enterprise Financing: A Note on Some of the Empirical Implications of a Pecking Order. Journal of Business Finance \& Accounting, $29(3$ \& 4), $557-579$. http://dx.doi.org/10.1111/1468-5957.00443

Wijst, N. V. D., \& Thurik, R. (1993). Determinants of Small Firm Debt Ratios: An Analysis of Retail Panel Data. Small Business Economics, 5(1), 55-65. http://dx.doi.org/10.1007/BF01539318 